\title{
Use of Biosynthetic Human C-peptide in the Measurement of Insulin Secretion Rates in Normal Volunteers and Type I Diabetic Patients
}

K. S. Polonsky, J. Licinio-Paixao, B. D. Given, W. Pugh, P. Rue, J. Galloway, T. Karrison, and B. Frank

Departments of Medicine and Statistics, University of Chicago, Pritzker School of Medicine,

Chicago, Illinois 60637; and Eli Lilly and Company, Indianapolis, Indiana 46285

\begin{abstract}
We undertook this study to examine the accuracy of plasma $\mathrm{C}$ peptide as a marker of insulin secretion. The peripheral kinetics of biosynthetic human C-peptide (BHCP) were studied in 10 normal volunteers and 7 insulin-dependent diabetic patients. Each subject received intravenous bolus injections of BHCP as well as constant and variable rate infusions. After intravenous bolus injections the metabolic clearance rate of BHCP $(3.8 \pm 0.1 \mathrm{ml} /$ $\mathrm{kg}$ per min, mean \pm SEM) was not significantly different from the value obtained during its constant intravenous infusion $(3.9 \pm 0.1 \mathrm{ml} / \mathrm{kg}$ per $\mathrm{min})$. The metabolic clearance rate of $\mathrm{C}$ peptide measured during steady state intravenous infusions was constant over a wide concentration range.

During experiments in which BHCP was infused at a variable rate, the peripheral concentration of $\mathrm{C}$-peptide did not change in proportion to the infusion rate. Thus, the infusion rate of BHCP could not be calculated accurately as the product of the $\mathrm{C}$-peptide concentration and metabolic clearance rate. However, the nonsteady infusion rate of BHCP could be accurately calculated from peripheral $\mathbf{C}$-peptide concentrations using a two-compartment mathematical model when model parameters were derived from the C-peptide decay curve in each subject. Application of this model to predict constant infusions of $\mathrm{C}$-peptide from peripheral $\mathrm{C}$-peptide concentrations resulted in model generated estimates of the $C$-peptide infusion rate that were $101.5 \pm 3.4 \%$ and $100.4 \pm 2.8 \%$ of low and high dose rates, respectively. Estimates of the total quantity of $\mathrm{C}$-peptide infused at a variable rate over 240 min based on the two-compartment model represented 104.6 $\pm 2.4 \%$ of the amount actually infused. Application of this approach to clinical studies will allow the secretion rate of insulin to be estimated with considerable accuracy.

The insulin secretion rate in normal subjects after an overnight fast was $89.1 \mathrm{pmol} / \mathrm{min}$, which corresponds with a basal 24-h secretion of $18.6 \mathrm{U}$.
\end{abstract}

\section{Introduction}

The concentration of C-peptide in plasma and urine has been extensively used as a means of assessing beta cell secretory activity (1-5). The rationale for this approach depends on the fact that the liver is the major site of insulin metabolism, variably extracting $\sim 50 \%$ of insulin delivered to it (6-11). C-peptide is

Address correspondence to Dr. Polonsky, Department of Medicine, Box 435, 5841 S. Maryland Ave., Chicago IL 60637. 1985.

Received for publication 25 June 1985 and in revised form 28 August

J. Clin. Invest.

(c) The American Society for Clinical Investigation, Inc.

0021-9738/86/01/0098/08 \$1.00

Volume 77, January 1986, 98-105 cosecreted from the beta cell on an equimolar basis with insulin (12) but does not undergo significant hepatic extraction (1315). It has therefore been suggested that peripheral C-peptide levels more accurately reflect pancreatic insulin secretion rates than do peripheral insulin levels and that urinary C-peptide levels can be used to document changes in beta cell secretion.

Current knowledge of the kinetics of human C-peptide is incomplete and is based largely on a single study in which Faber and co-workers (16) administered intravenous bolus injections of synthetic human C-peptide to normal volunteers and Type I diabetic patients. The half-life of the peptide was $33.5 \mathrm{~min}$ and its metabolic clearance rate was $4.4 \mathrm{ml} / \mathrm{kg}$ per min in normal subjects. Because of lack of additional C-peptide, the metabolic clearance rate of $C$-peptide could only be studied by the constant infusion technique in a single subject.

A number of approaches have been proposed for the derivation of insulin secretion rates from peripheral C-peptide concentrations (1-5). However, due to lack of availability of sufficient quantities of human C-peptide for clinical studies, the accuracy with which insulin secretion can be derived from peripheral C-peptide concentrations using these indirect approaches has not been determined.

Application of recombinant DNA technology has led to the production of sufficient quantities of well characterized biosynthetic human C-peptide for human studies (17). Availability of this material has provided the opportunity to study how accurately the secretion rate of $\mathrm{C}$-peptide and therefore insulin can be derived from peripheral C-peptide concentrations. The results of studies that have addressed these questions are detailed in this report.

\section{Methods}

\section{Subjects}

Experiments were performed in 10 normal volunteers ( 5 males, 5 females) and 7 insulin-deficient Type I diabetic patients ( 4 males, 3 females). Ages were similar in the normal $(28.0 \pm 1.7 \mathrm{yr})$ and diabetic subjects $(28.0 \pm 3.1$ yr). All subjects were within $10 \%$ of ideal body weight. The diabetic patients were insulin-dependent with a disease duration of $9.4 \pm 2.3 \mathrm{yr}$ (range, 3-18). None had clinically significant vascular, renal, eye, or neurological complications. All studies were carried out in the Clinical Research Center of the University of Chicago, IL. Subjects signed written informed consent and the protocols were approved by the Institutional Review Board.

\section{Biosynthetic human C-peptide}

Biosynthetic human C-peptide (BHCP) ${ }^{1}$ was produced by recombinant DNA technology as previously described (17). The material was shown to have the amino acid composition expected for human C-peptide and co-eluted with C-peptide isolated from human pancreas from both $\mathrm{C} 8$

1. Abbreviations used in this paper: $\mathrm{BHCP}$, biosynthetic human C-peptide; HPLC, high pressure liquid chromatography. 
and $\mathrm{C} 18$ reverse-phase high pressure liquid chromatography (HPLC) systems. C-peptide immunoreactivity isolated from human plasma following its intravenous administration co-eluted on reverse-phase HPLC with the BHCP standard and with endogenous C-peptide extracted from normal human serum (data not shown).

\section{Experimental protocols}

We performed studies on volunteers after they had fasted overnight. Diabetic subjects received a continuous intravenous infusion of insulin adjusted to maintain the plasma glucose concentration in the euglycemic range. During each experiment, an intravenous sampling catheter was inserted into the dorsum of the hand and an infusion catheter was inserted into a vein on the opposite arm. The hand with the sampling catheter was maintained in a heating blanket to ensure arterialization of the venous sample. Each normal volunteer and diabetic subject was studied on four separate occasions over a period of 3-4 wk. The orders of the studies were randomized. During these four studies BHCP was administered by intravenous bolus injection as well as constant and variable rate intravenous infusions. Details of each study protocol are outlined below.

1. Bolus intravenous injections of BHCP. Each subject received an intravenous bolus injection of BHCP on two occasions. One bolus was administered in the presence of basal endogenous beta cell secretion, while on the other occasion somatostatin was infused to suppress endogenous beta cell secretion. This experimental design allowed us to determine $(a)$ the reproducibility of the concentration response to a bolus injection of C-peptide; $(b)$ the effect of somatostatin on the clearance kinetics of C-peptide and $(c)$ the accuracy with which the kinetic parameters of administered BHCP could be determined in the presence of endogenous beta cell secretion. After a 60 -min baseline during which endogenous $\mathrm{C}$-peptide was measured at 10 -min intervals, each subject received a bolus injection of $50 \mathrm{nmol} \mathrm{BHCP} .^{2}$ Plasma C-peptide concentrations were measured at the following time points after the bolus: $2,3,4,5,6,7,8,9,10,11,14,17,20,25,30,35,40,45,50,55,60,70$, $80,90,100,110,120,140,160$, and $180 \mathrm{~min}$. Glucose and insulin concentrations were measured at 10 -min intervals. The experiment utilizing somatostatin suppression followed a similar protocol except that after the 60 -min baseline, subjects received a bolus $(50 \mu \mathrm{g})$ and constant infusion of somatostatin $(500 \mu \mathrm{g} / \mathrm{h})$. The somatostatin was infused alone for 60 min during which C-peptide and insulin were measured at 10min intervals to document suppression of endogenous beta cell secretion. $50 \mathrm{nmol}$ of C-peptide was then injected intravenously and samples were drawn at the time points listed above. The somatostatin infusion was maintained throughout the experiment.

2. Constant infusions of BHCP. During a $60-\mathrm{min}$ baseline period endogenous $C$-peptide concentrations were measured at 10 -min intervals. A low dose BHCP infusion ( $3 \mathrm{pmol} / \mathrm{kg}$ per $\mathrm{min}$ ) was then administered for $120 \mathrm{~min}$. The infusion rate was subsequently increased in a single step to $30 \mathrm{pmol} / \mathrm{kg}$ per min for an additional $120 \mathrm{~min}$. C-peptide, insulin, and glucose were measured at 5-10-min intervals during the BHCP infusions. In these and the experiments described below, the infusion rate of BHCP was derived using C-peptide concentrations in aliquots of the infusate drawn from the tip of the infusion catheter as it entered the subject.

3. Variable infusions of BHCP. Endogenous C-peptide, insulin, and glucose were measured at 10 -min intervals during a 60 -min baseline period. BHCP was then infused intravenously at a rate of $3 \mathrm{pmol} / \mathrm{kg}$ per $\mathrm{min}$ for $60 \mathrm{~min}$. Subsequently, the infusion rate was progressively increased at 5 -min intervals to reach a peak of $21 \mathrm{pmol} / \mathrm{kg}$ per min by $35 \mathrm{~min}$. This rate was maintained for $15 \mathrm{~min}$. The infusion rate was then progressively reduced at 10 -min intervals over $70 \mathrm{~min}$ to the basal rate, which was administered for an additional $60 \mathrm{~min}$. C-peptide was measured at 5-10-min intervals, and insulin and glucose were measured at $10-20-\mathrm{min}$ intervals. This protocol was designed to simulate the pattern of change in insulin secretion reported to occur after oral glucose ingestion (2).

2. The molecular weight of human C-peptide is 3,021 ; therefore, to convert nanomoles to micrograms, multiply by 3.021 .

\section{Calculations}

In all analyses the mean endogenous $C$-peptide concentration in the base line was subtracted from subsequent $C$-peptide levels measured after BHCP administration. The validity of this approach, which assumes that C-peptide does not affect its own secretion, was supported by the observation that peripheral insulin concentrations did not change as a result of the BHCP administration (see below). Preliminary experiments performed in seven normal volunteers showed that the current dose of somatostatin resulted in suppression of plasma $C$-peptide concentrations to below the detection limit of the assay $(<0.02 \mathrm{pmol} / \mathrm{ml})$ in all subjects. The baseline C-peptide concentration was therefore assumed to be zero in the experiments in which somatostatin was infused. In addition, preliminary experiments performed in four normal volunteers revealed that plasma C-peptide concentrations did not change significantly during a 4-h saline infusion administered after an overnight fast. C-peptide concentrations at the beginning and end of these experiments were $0.55 \pm 0.08$ $\mathrm{pmol} / \mathrm{ml}$ and $0.51 \pm 0.05 \mathrm{pmol} / \mathrm{ml}$, respectively $(P=0.2)$.

The C-peptide decay curves were resolved into the sum of two exponentials by iterative, nonlinear, least squares regression analysis. The metabolic clearance rate of $\mathrm{C}$-peptide was calculated from these decay curves as the ratio of the amount of C-peptide in the bolus to the integrated area under the plasma concentration curve. The metabolic clearance rate of BHCP was calculated during the constant infusion experiments as the ratio of the infusion rate to the steady state plasma concentration.

Since C-peptide and insulin are cosecreted in equal concentration from the beta cell but $C$-peptide is not extracted by the liver, the constant and variable infusions of BHCP described above can be considered to be analogous to the intraportal administration of $\mathrm{C}$-peptide. To determine if the infusion rates of $\mathrm{C}$-peptide during both the constant, and variable rate, infusion experiments could be accurately determined by analysis of peripheral C-peptide concentrations, we analyzed the concentrations of C-peptide achieved during these experiments, and we calculated the infusion rate of $\mathrm{C}$-peptide according to a two-compartment mathematical model proposed by Eaton and co-workers (2). This model assumes that C-peptide distributes into a central compartment, from which sampling occurs, and into a peripheral extravascular compartment. The central compartment consists of the plasma space and tissues in rapid equilibration with plasma. Fractional rate constants $K_{1}$ and $K_{2}$ describe the rate at which $C$-peptide passes from the central to the peripheral compartment $\left(K_{1}\right)$ and back again to the plasma compartment $\left(K_{2}\right)$. According to this model, $\mathrm{C}$-peptide is irreversibly metabolized from the central compartment, $K_{3}$ being the rate constant that describes this process. The model is depicted in the diagram below.

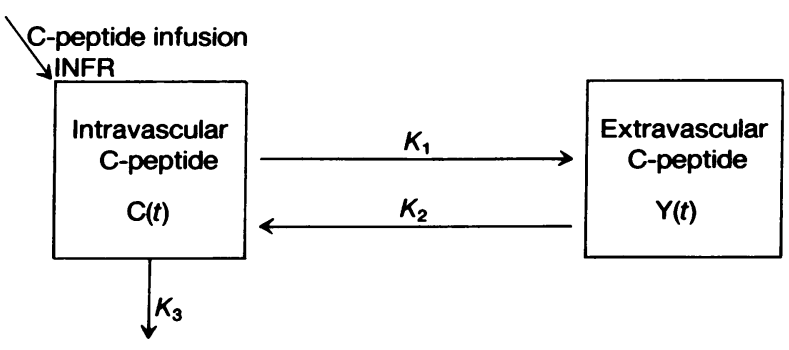

Scheme 1

$\mathrm{C}(t)$ represents the total amount of $\mathrm{C}$-peptide in the plasma compartment at time $t$, and $\mathrm{Y}(t)$ is the amount of $\mathrm{C}$-peptide in all extravascular sites.

The fractional rate constants and total initial distribution volume of C-peptide, which define the model parameters, can be derived by analysis of C-peptide decay curves using the equations of Metzler (18). In the current experiments $K_{1}, K_{2}$, and $K_{3}$, and the C-peptide volume of distribution $V_{\mathrm{p}}$ were estimated separately in each subject using weighted, iterative, nonlinear least squares regression analysis of individual decay curves. The weight was defined as the reciprocal of the square of the Cpeptide concentration. The appropriate equations utilized in this analysis are listed below. 
$\mathrm{C}(t)=\frac{\text { Dose }}{V_{\mathrm{p}}(\alpha-\beta)}\left[\left(\alpha-K_{2}\right) \mathrm{e}^{-\alpha t}-\left(\beta-K_{2}\right) \mathrm{e}^{-\beta t}\right]$,

where

$$
\alpha=1 / 2\left[K_{1}+K_{2}+K_{3}+\sqrt{\left(K_{1}+K_{2}+K_{3}\right)^{2}-4 K_{2} K_{3}}\right]
$$

and

$$
\beta=1 / 2\left[K_{1}+K_{2}+K_{3}-\sqrt{\left(K_{1}+K_{2}+K_{3}\right)^{2}-4 K_{2} K_{3}}\right] .
$$

Since in addition to intravenous bolus injections of C-peptide, each subject also received constant and variable rate $\mathrm{C}$-peptide infusions, it was possible to examine the accuracy with which this model could be applied to predicting the infusion rate of $\mathrm{C}$-peptide from peripheral $\mathrm{C}$ peptide concentrations. Individual model parameters derived in each normal subject or diabetic patient were used in the analysis. A least squares cubic spline was fit by computer to the discrete arterial C-peptide concentrations observed during the constant and variable $\mathrm{C}$-peptide infusions to obtain a smooth representation of the concentration curves in each subject. Predicted C-peptide infusion rates, INFR $(t)$, were generated according to the equation of Eaton et al. (2), which utilizes the smoothed C-peptide concentration curve and the estimated fractional rate constants and $C$-peptide distribution volume previously determined in the same subject by analysis of the C-peptide decay curves. At each sampling time during both the constant and variable BHCP infusions, the actual BHCP infusion rate was compared with the infusion rate derived by the above analyses of peripheral $\mathrm{C}$-peptide concentrations. The absolute difference between the actual infusion rate and the rate predicted by the model was calculated at each sampling time. The mean difference in each experiment was expressed as a percentage of the mean actual infusion rate. This value was used as a measure of the overall error associated with the use of the two-compartment model. Absolute differences between the actual and predicted infusion rates were used in the calculation so that positive and negative values would not cancel each other. As a further measure of the accuracy of the model, the area under the actual infusion rate curve and the curve predicted by the model were compared.

\section{Sample collection and analytical techniques}

Blood samples for insulin were allowed to clot at room temperature and the serum was stored at $-20^{\circ} \mathrm{C}$ until assayed. C-peptide and glucose samples were drawn into tubes at $4^{\circ} \mathrm{C}$ containing $500 \mathrm{KIU} / \mathrm{ml}$ Trasylol and $1.2 \mathrm{mg} / \mathrm{ml}$ EDTA. Plasma was separated immediately and stored frozen until assayed.

Serum insulin was assayed by a double antibody technique (19). Plasma glucose was measured with a glucose analyzer (Yellow Springs Instrument Co., Yellow Springs, $\mathrm{OH}$ ). Human C-peptide immunoreactivity in plasma was measured as previously described. BHCP and ${ }^{125} \mathrm{I}-$ Tyr-BHCP were used as assay standard and tracer, respectively $(20,21)$.

\section{Data analysis}

The significance of differences between group means was evaluated by a two-tailed paired or unpaired $t$ test or multivariate analysis where appropriate. Results are expressed as mean $\pm \mathrm{SEM}$, and $P<0.05$ was considered statistically significant. All calculations were performed using the Statistical Analysis System Version 82.3 (Statistical Analysis System Institute Inc., Cary, NC).

\section{Results}

Effect of BHCP administration on insulin and glucose concentrations in normal subjects. Fasting insulin and glucose concen-

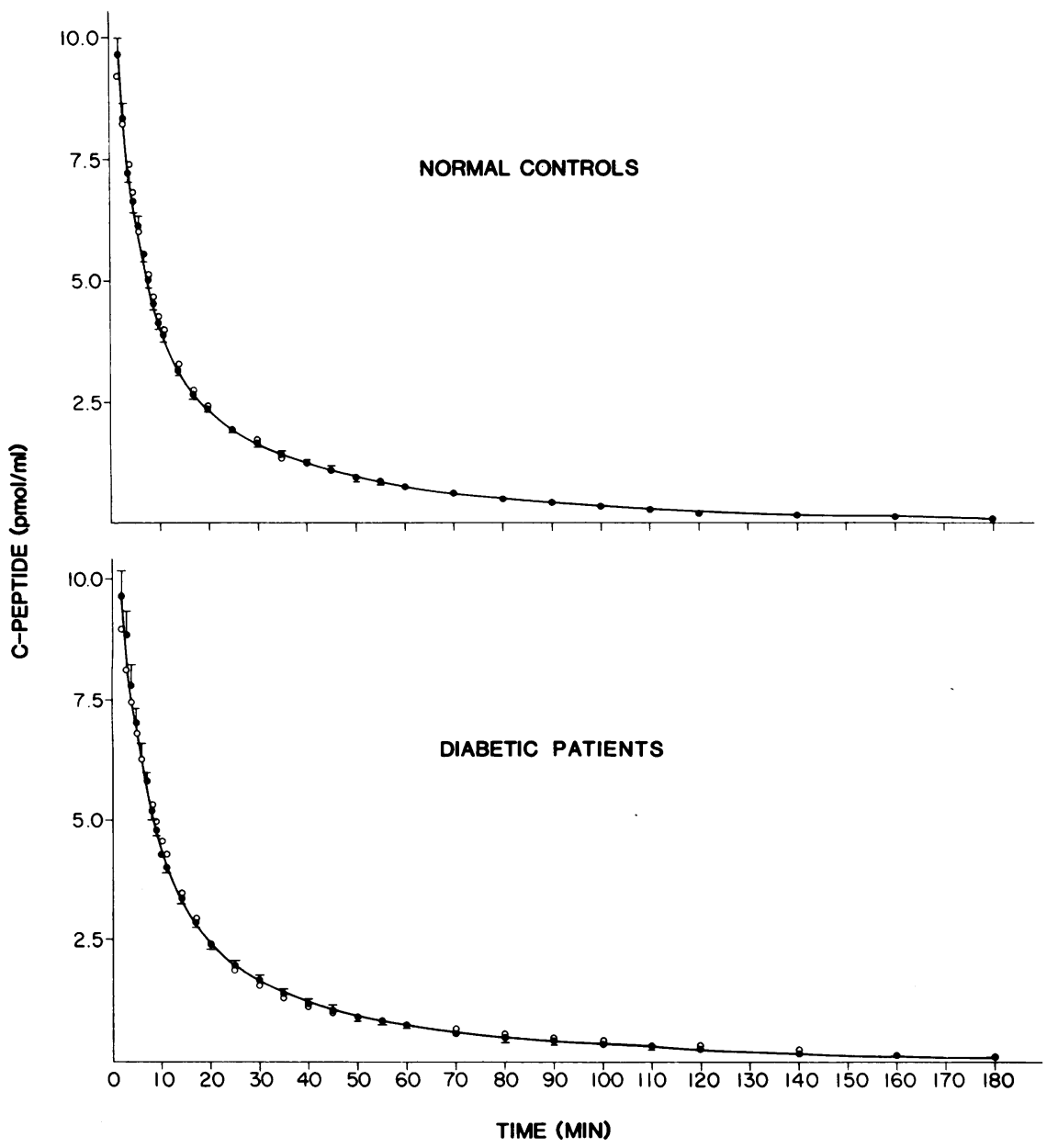

Figure 1. Mean plasma C-peptide concentrations $(\bullet)$ after intravenous bolus injections of biosynthetic human C-peptide in 10 normal subjects (top) and 7 Type I diabetic patients (bottom). Open circles depict mean fitted Cpeptide concentrations derived from the twocompartment model applied to the data for each individual subject as described in Methods. Mean fitted values are shown only at time points where they were different from the average measured C-peptide concentrations. In this and subsequent groups the $\mathrm{C}$-peptide level measured during the baseline endogenous sampling period in each experiment was subtracted from C-peptide levels measured after administration of BHCP. 
trations before administration of the BHCP bolus were 7.2 \pm 0.7 $\mu \mathrm{U} / \mathrm{ml}(49.7 \pm 4.8 \mathrm{fmol} / \mathrm{ml})$ and $90.1 \pm 2.0 \mathrm{mg} / \mathrm{dl}(5.0 \pm 0.10$ $\mathrm{mmol} /$ liter), respectively. Mean levels after administration of the bolus were $6.1 \pm 0.4 \mu \mathrm{U} / \mathrm{ml}(42.1 \pm 2.8 \mathrm{fmol} / \mathrm{ml})$ and $90.0 \pm 2.2$ $\mathrm{mg} / \mathrm{dl}(5.0 \pm 0.12 \mathrm{mmol} / \mathrm{liter})$, respectively. A similar lack of effect of BHCP on glucose and insulin concentrations was observed during the constant and variable rate infusion experiments. Somatostatin administration lowered the concentration of insulin to below the detection limit of the assay in all of these subjects.

Plasma concentrations of $C$-peptide. Mean plasma C-peptide concentrations after the intravenous bolus injections of BHCP are shown in Fig. 1. In the control subjects, the levels were not significantly different in the experiments with and without somatostatin after subtraction of the baseline $C$-peptide values in the latter experiments, and therefore, we report mean plasma levels and parameter estimates from the two protocols (Fig. 1). In the diabetic subjects, whose serum C-peptide concentrations were below the detection limit of the assay before administration of the bolus injections, the results of the decay curves with and without somatostatin were not statistically different. The concentration measured 2 min after the bolus was $9.7 \pm 0.4 \mathrm{pmol} /$ $\mathrm{ml}$ in the normals and $9.7 \pm 0.6 \mathrm{pmol} / \mathrm{ml}$ in the diabetics. By $180 \mathrm{~min}$, concentrations had fallen to $0.08 \pm 0.01$ and $0.14 \pm 0.01$ $\mathrm{pmol} / \mathrm{ml}$ in the two groups, respectively.

During the constant infusions of C-peptide, steady state plasma levels were only achieved after $100 \mathrm{~min}$ at each infusion rate. The steady state plasma concentration during the low dose infusion was $0.837 \pm 0.039 \mathrm{pmol} / \mathrm{ml}$ and during the high dose infusion the level increased to $9.123 \pm 0.215 \mathrm{pmol} / \mathrm{ml}$ in the normal subjects. Corresponding values in the diabetics were
$0.886 \pm 0.021$ and $9.476 \pm 0.345 \mathrm{pmol} / \mathrm{ml}$, respectively. The differences between the normals and diabetics were not significant and mean data are shown in Fig. 2 (top).

During the variable infusion protocol (Fig. 3, middle) the peripheral concentration of $C$-peptide at the end of the $60 \mathrm{~min}$ baseline infusion was $0.800 \pm 0.08 \mathrm{pmol} / \mathrm{ml}$. This concentration then increased progressively to reach a peak of $4.96 \pm 0.17 \mathrm{pmol} /$ $\mathrm{ml}$ by $70 \mathrm{~min}$. The concentration fell progressively as the infusion rate was reduced but had not returned to baseline by the end of the experiment.

Metabolic clearance rate of $C$-peptide. The decay curves following the bolus injections of $\mathrm{C}$-peptide were individually resolved into the sum of two linear exponentials. The respective half-lives of each exponential were $5.2 \pm 0.4$ and $36.5 \pm 1.7 \mathrm{~min}$ in the normals and $6.9 \pm 0.4$ and $45.3 \pm 1.4 \mathrm{~min}$ in the diabetics ( $P<0.02$ for each parameter). The metabolic clearance rate derived from analysis of the decay curves was $4.0 \pm 0.2 \mathrm{ml} / \mathrm{kg}$ per $\mathrm{min}$ in the normals and $3.6 \pm 0.2 \mathrm{ml} / \mathrm{kg}$ per $\mathrm{min}$ in the diabetics $(P<0.001)$.

In the normal subjects the metabolic clearance rate of $\mathrm{C}$ peptide measured during its constant infusion was similar at the low $(4.0 \pm 0.2 \mathrm{ml} / \mathrm{kg}$ per $\mathrm{min})$ and high $(4.0 \pm 0.2 \mathrm{ml} / \mathrm{kg}$ per $\mathrm{min})$ infusion rates. Corresponding values in the diabetics were $3.6 \pm 0.1$ and $3.9 \pm 0.2 \mathrm{ml} / \mathrm{kg}$ per min. As is apparent, calculation of the metabolic clearance rate after bolus injection and during steady state infusion gave similar values in both the normal and diabetic subjects.

Prediction of infusion rate of BHCP from peripheral C-peptide concentrations according to a two-compartment mathematical model. To determine if the $\mathrm{C}$-peptide infusion rate could

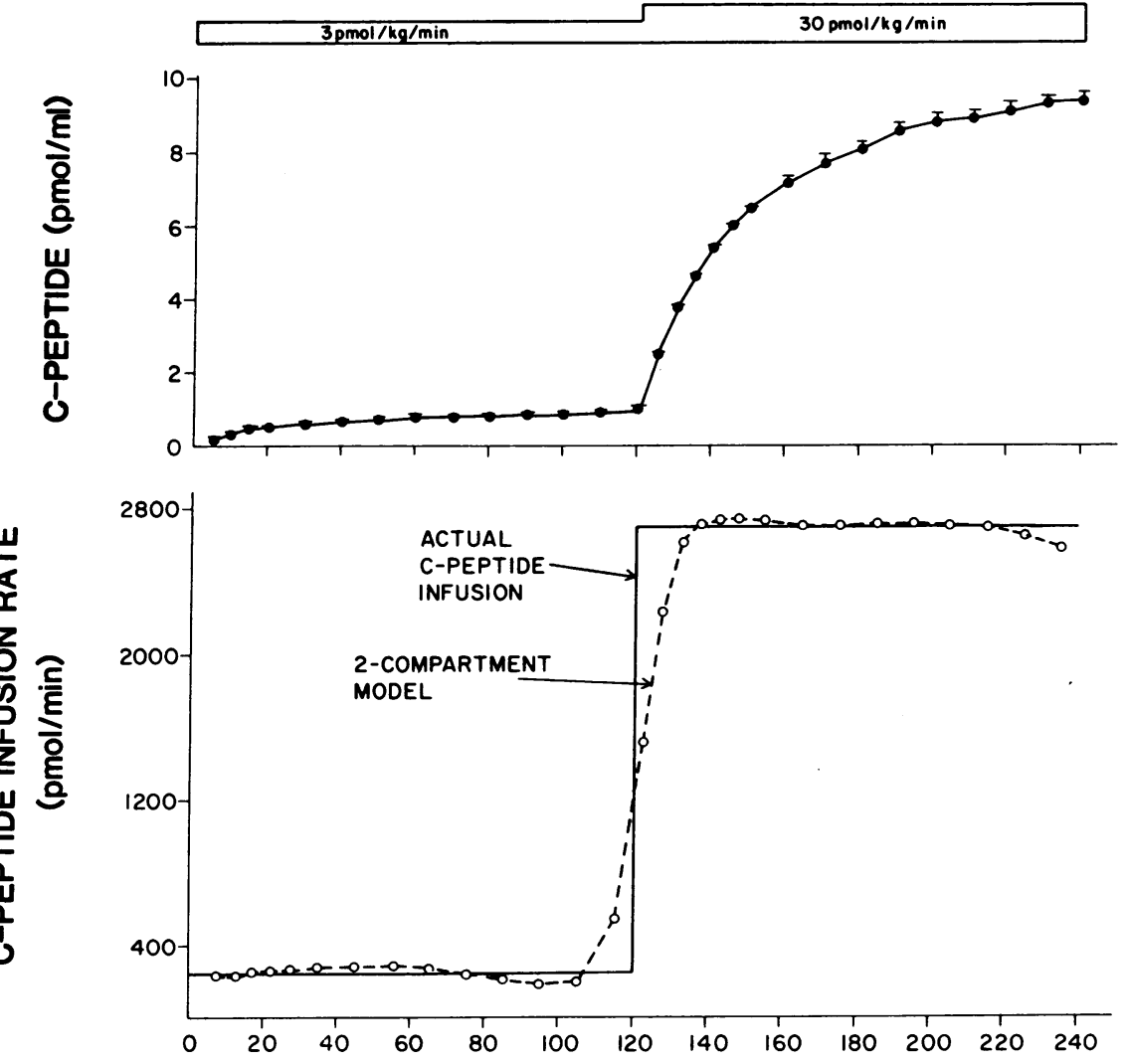

TIME (MIN)
Figure 2. Constant infusion of biosynthetic human C-peptide in 10 normal volunteers and 7 Type I diabetic subjects at rates of $3 \mathrm{pmol} / \mathrm{kg}$ per min and $30 \mathrm{pmol} / \mathrm{kg}$ per min for $120 \mathrm{~min}$ each. Mean plasma concentrations of $\mathrm{C}$-peptide from all 17 subjects are shown in the top panel. The actual infusion rate of C-peptide (-) is shown in the bottom panel in comparison to mean C-peptide infusion rates calculated according to a two-compartment mathematical model (- - O- -). 

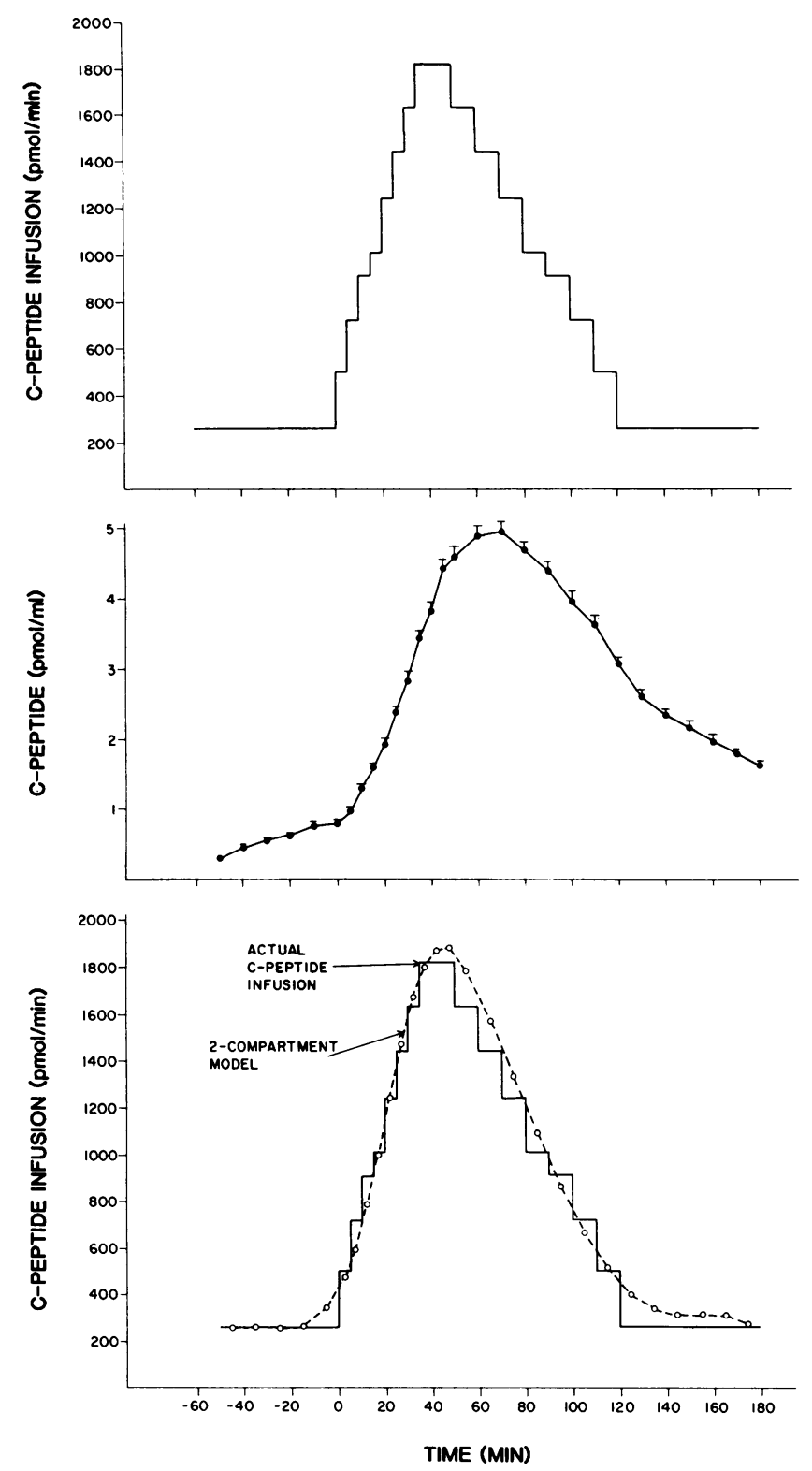

Figure 3. Variable infusions of biosynthetic human C-peptide in 10 normal volunteers and 7 Type I diabetic subjects. The infusion rate of C-peptide is shown in the top panel and mean plasma concentrations are in the middle panel. The bottom panel depicts the actual infusion rate of $\mathrm{C}$-peptide $(-)$ in comparison to mean infusion rates calculated according to a two-compartment mathematical model $(--0--)$.

be estimated by the use of the two-compartment mathematical model described above, fractional rate constants and C-peptide distribution volume were derived for each subject from their individual decay curves as shown in Table I. Parameter values given for each subject are the average of the two values obtained from the two bolus injection protocols. The model parameters in the normal controls were: $K_{1}, 0.057 \pm 0.006 \mathrm{~min}^{-1}$; $K_{2}, 0.054 \pm 0.006 \mathrm{~min}^{-1} ; K_{3}, 0.060 \pm 0.002 \mathrm{~min}^{-1}$; and distribution volume, $65.5 \pm 2.5 \mathrm{ml} / \mathrm{kg}$. Corresponding values in the diabetics $\left(0.037 \pm 0.004 \mathrm{~min}^{-1}, 0.031 \pm 0.002 \mathrm{~min}^{-1}, 0.052 \pm 0.003\right.$ $\mathrm{min}^{-1}$, and $65.5 \pm 2.0 \mathrm{ml} / \mathrm{kg}$ ) were significantly different from the normals by multivariate Hotelling-Hawley Trace statistic ( $P$ $<0.0003)$. 
Table I. Metabolic and Kinetic Parameters of Biosynthetic Human C-peptide

\begin{tabular}{|c|c|c|c|c|c|c|}
\hline Subject no. & $\begin{array}{l}\text { MCR, } \\
\text { constant infusion }\end{array}$ & $\begin{array}{l}\text { MCR, } \\
\text { bolus injection }\end{array}$ & $K_{1}$ & $K_{2}$ & $K_{3}$ & $\begin{array}{l}\text { Distribution } \\
\text { volume }\end{array}$ \\
\hline & $\mathrm{ml} / \mathrm{kg}$ per min & $\mathrm{ml} / \mathrm{kg}$ per min & $\mathrm{min}^{-1}$ & $\min ^{-1}$ & $\min ^{-1}$ & $\mathrm{ml} / \mathrm{kg}$ \\
\hline \multicolumn{7}{|c|}{ Normal controls } \\
\hline 1 & 4.4 & 3.8 & 0.036 & 0.035 & 0.060 & 60.3 \\
\hline 2 & 4.2 & 4.2 & 0.044 & 0.034 & 0.054 & 71.5 \\
\hline 3 & 3.6 & 4.0 & 0.080 & 0.069 & 0.062 & 61.8 \\
\hline 4 & 4.1 & 4.0 & 0.030 & 0.042 & 0.060 & 72.8 \\
\hline 5 & 3.1 & 3.9 & 0.082 & 0.069 & 0.059 & 59.6 \\
\hline 6 & 4.5 & 4.3 & 0.042 & 0.034 & 0.053 & 79.9 \\
\hline 7 & 3.7 & 3.9 & 0.072 & 0.083 & 0.059 & 63.4 \\
\hline 8 & 4.3 & 4.3 & 0.060 & 0.051 & 0.063 & 65.6 \\
\hline 9 & 3.8 & 3.8 & 0.052 & 0.048 & 0.053 & 68.7 \\
\hline 10 & $\underline{4.3}$ & $\underline{4.0}$ & $\underline{0.070}$ & $\underline{0.074}$ & $\underline{0.072}$ & $\underline{51.7}$ \\
\hline Mean & 4.0 & 4.0 & 0.057 & 0.054 & 0.060 & 65.5 \\
\hline \pm SEM & $\underline{0.1}$ & $\underline{0.1}$ & $\underline{0.006}$ & $\underline{0.006}$ & $\underline{0.002}$ & 2.5 \\
\hline \multicolumn{7}{|c|}{ Diabetic patients } \\
\hline 1 & 3.6 & 3.4 & 0.046 & 0.031 & 0.069 & 46.8 \\
\hline 2 & 3.7 & 3.6 & 0.032 & 0.026 & 0.050 & 65.7 \\
\hline 3 & 4.0 & 3.7 & 0.022 & 0.025 & 0.055 & 60.9 \\
\hline 4 & 3.5 & 3.4 & 0.051 & 0.042 & 0.046 & 69.1 \\
\hline 5 & 3.9 & 3.7 & 0.041 & 0.030 & 0.047 & 73.9 \\
\hline 6 & 4.0 & 3.2 & 0.036 & 0.034 & 0.048 & 67.8 \\
\hline 7 & $\underline{3.6}$ & $\underline{4.0}$ & $\underline{0.028}$ & $\underline{0.029}$ & $\underline{0.051}$ & $\underline{74.4}$ \\
\hline Mean & 3.8 & 3.6 & 0.037 & 0.031 & 0.052 & 65.5 \\
\hline \pm SEM & $\underline{0.1}$ & $\underline{0.1}$ & $\underline{0.004}$ & $\underline{0.002}$ & $\underline{0.003}$ & 3.6 \\
\hline Mean & 3.9 & 3.8 & 0.048 & 0.044 & 0.057 & 65.5 \\
\hline \pm SEM & 0.1 & 0.1 & 0.004 & 0.004 & 0.002 & 2.0 \\
\hline
\end{tabular}

The metabolic clearance rate (MCR) of biosynthetic human C-peptide was calculated during constant infusions and after intravenous bolus injections. Parameters for a two-compartment model were derived by iterative nonlinear least squares regression analysis of $\mathrm{C}$-peptide decay curves.

fusions (13-15). The results of the present experiments, therefore, are equally applicable to both the physiological intraportal route and the peripheral route of C-peptide delivery.

The metabolic clearance rate of C-peptide was similar during low $(3.9 \pm 0.1 \mathrm{ml} / \mathrm{kg}$ per $\mathrm{min})$ and high dose exogenous infusions $(4.0 \pm 0.1 \mathrm{ml} / \mathrm{kg}$ per min). The plasma levels during the latter infusions exceeded those encountered under most physiological circumstances. Furthermore, the metabolic clearance rate measured after intravenous bolus injection of C-peptide (3.8 \pm 0.1 $\mathrm{ml} / \mathrm{kg}$ per $\mathrm{min}$ ) was not significantly different from the metabolic clearance rate measured during constant intravenous infusions $(3.9 \pm 0.1 \mathrm{ml} / \mathrm{kg}$ per min). These values are similar to those obtained by Faber et al. (16). Although the metabolic clearance of $\mathrm{C}$-peptide is independent of its plasma concentration, the clearance rate varies amongst indiviudals (Table I). The range of $\mathrm{C}$ peptide metabolic clearance rate in the present studies was 3.1 to $4.5 \mathrm{ml} / \mathrm{kg}$ per min and was lower in diabetic patients than in normal controls, although the difference was statistically significant only after the bolus injection. This suggests that derivation of kinetic parameters of C-peptide in individual subjects should increase the accuracy with which its secretion rate can be derived from peripheral plasma concentrations.

The slow equilibration time and clearance rate of C-peptide must be taken into account in the interpretation of peripheral $\mathrm{C}$-peptide concentrations as shown during the variable rate $\mathrm{C}$ - peptide infusions. During these experiments, the plasma C-peptide concentration increased more slowly than the infusion rate as it was increasing and fell more slowly than the infusion rate as it was being reduced. Furthermore, since the half-life of BHCP is greater than $30 \mathrm{~min}$, its plasma concentration would not be expected to change rapidly with short-term changes in the infusion rate. Thus, under nonsteady state conditions, the peripheral concentration of $\mathrm{C}$-peptide does not change in direct proportion to changes in its secretion rate and as a result the secretion rate of insulin cannot be accurately derived from plasma $\mathrm{C}$ peptide concentrations by a simple single compartmental mathematical analysis.

Use of a two-compartment mathematical model (2) considerably increased the accuracy with which the C-peptide infusion rate could be estimated from peripheral $C$-peptide concentrations. According to this model, C-peptide distributes into two compartments: a central compartment consisting of plasma and tissues in rapid equilibration with plasma, and a peripheral extravascular compartment. Analysis of the C-peptide decay curves in this study has shown that on the average, $4.8 \pm 0.4 \%$ of $C$ peptide in the central compartment moves to the peripheral compartment per minute and $4.4 \pm 0.4 \%$ of $C$-peptide in the peripheral compartment is transferred back to plasma. $5.7 \pm 0.2 \%$ of C-peptide is irreversibly lost from the central compartment per minute. As the infusion rate of $C$-peptide increases, move- 
Table II. Prediction of C-peptide Infusion Rates Using a Two-compartment Model

\begin{tabular}{|c|c|c|c|c|}
\hline \multirow[b]{2}{*}{ Subject no. } & \multicolumn{2}{|l|}{ Constant infusions } & \multicolumn{2}{|c|}{ Variable rate infusions } \\
\hline & $\begin{array}{l}\text { Low dose } \\
\text { A }\end{array}$ & $\begin{array}{l}\text { High dose } \\
\text { B }\end{array}$ & C & $\begin{array}{l}\text { Total dose } \\
\text { D }\end{array}$ \\
\hline & Predicted/actual $\%$ & Predicted/actual \% & \% error & Predicted/actual \% \\
\hline \multicolumn{5}{|c|}{ Normal controls } \\
\hline 1 & 88.2 & 93.8 & 15.4 & 89.7 \\
\hline 2 & 107.9 & 101.2 & 8.7 & 101.6 \\
\hline 3 & 98.4 & 119.4 & 29.7 & 110.3 \\
\hline 4 & 103.3 & 117.0 & 16.4 & 121.7 \\
\hline 5 & 122.5 & 110.5 & 19.8 & 113.6 \\
\hline 6 & 92.0 & 104.4 & 9.7 & 110.3 \\
\hline 7 & 106.1 & 101.9 & 14.6 & 90.1 \\
\hline 8 & 104.5 & 101.8 & 14.2 & 87.8 \\
\hline 9 & 107.5 & 98.6 & 18.3 & 110.2 \\
\hline 10 & 94.2 & 78.5 & 17.6 & 109.0 \\
\hline Mean & 102.5 & 102.7 & 15.4 & 104.4 \\
\hline \pm SEM & 3.1 & 3.7 & 1.2 & 3.7 \\
\hline \multicolumn{5}{|c|}{ Diabetic patients } \\
\hline 1 & 90.6 & 93.9 & 8.1 & 96.5 \\
\hline 2 & 94.9 & 94.3 & 7.6 & 101.0 \\
\hline 3 & 79.7 & 85.1 & 14.3 & 97.0 \\
\hline 4 & 94.6 & 105.1 & 9.0 & 107.4 \\
\hline 5 & 139.3 & 88.1 & 10.0 & 110.1 \\
\hline 6 & 92.8 & 93.9 & 7.8 & 106.1 \\
\hline 7 & 108.2 & 119.0 & $\underline{15.9}$ & 116.0 \\
\hline Mean & 100.0 & 97.1 & 10.4 & 104.9 \\
\hline \pm SEM & 7.3 & 4.4 & 1.1 & 2.7 \\
\hline Mean & 101.5 & 100.4 & 13.4 & 104.6 \\
\hline \pm SEM & 3.4 & 2.8 & 1.1 & 2.4 \\
\hline
\end{tabular}

The constant C-peptide infusion rates derived by the two-compartment model are expressed as a percentage of the actual infusion rate (columns $\mathrm{A}$ and B). During the variable rate infusion experiments absolute differences between the actual and model generated infusion rates were calculated as a percentage of the actual infusion rate as shown in column $\mathrm{C}$. The total amount of $\mathrm{C}$-peptide infused during this experiment predicted by the two-compartment model expressed as a percentage of the actual amount is shown in column D.

ment of C-peptide from the central to peripheral compartment results in the finding that the plasma concentration of $C$-peptide increases more slowly than the infusion rate. As the secretion rate of C-peptide falls, $\mathrm{C}$-peptide in the peripheral compartment moves into the plasma, thus slowing its disappearance from this compartment and contributing to its prolonged half-life. The compartmental distribution of C-peptide is also responsible for the observation shown in Fig. 3 that the same C-peptide infusion rate results in a higher peripheral C-peptide concentration when the overall direction of secretion is falling than when it is increasing. Note that Sherwin et al. (36) have proposed a threecompartment model for the kinetic analysis of insulin.

Application of the two-compartment model to analysis of peripheral concentrations of C-peptide measured during its intravenous infusion allowed the infusion rates to be accurately estimated. Thus, during constant infusions of BHCP, estimates of the infusion rate of $C$-peptide were $101.5 \pm 3.4$ and $100.4 \pm 2.8 \%$ of the actual infusion rates at the low and high doses, respectively. Estimates of the total amount of C-peptide infused during the variable infusion experiments based on the model were $104.6 \pm 2.4 \%$ of the amount actually infused. The mean absolute error associated with the use of the model at discrete time points during each experiment represented $13.4 \pm 1.1 \%$ of the actual infusion rate of C-peptide (Table II). Using this model, we es- timated a basal insulin secretion rate of $18.6 \mathrm{U} / 24 \mathrm{~h}$, which is in close agreement with values of 21.64 and $24 \mathrm{U} / 24 \mathrm{~h}$ previously reported by Eaton et al. (2) and Waldhäusl et al. (1), respectively.

In summary, the present studies indicate that because Cpeptide distributes into more than a single body compartment, its plasma concentration does not change in proportion to its secretion rate under nonsteady state conditions. This factor, combined with the fact that $\mathrm{C}$-peptide has a half-life in excess of $30 \mathrm{~min}$, limits the accuracy with which peripheral concentrations of $\mathrm{C}$-peptide reflect changes in insulin secretion while it is increasing and decreasing. Nevertheless, the above studies indicate that insulin secretion rates can be accurately quantitated from peripheral $\mathrm{C}$-peptide levels in different subjects, under nonsteady state conditions, if the appropriate kinetic parameters derived from analysis of C-peptide decay curves are applied to the compartmental analysis of endogenous $\mathrm{C}$-peptide concentrations.

\section{Acknowledgments}

The authors wish to pay tribute to Dr. Arthur H. Rubenstein for his unselfish support. His insight was an invaluable resource in many aspects of this study. We also wish to thank Annette Miller, who provided excellent medical care for the study subjects, and Virginia Kuvakos for expert secretarial assistance. 
Dr. Polonsky is the recipient of a Research Career Development Award from National Institutes of Health (AM-01234) and a Career Development Award from the Schweppe Foundation. This work was supported in part by National Institutes of Health grants AM 31842 and AM 20595; Eli Lilly and Co., and the Clinical Research Center (RR 00055).

\section{References}

1. Waldhäusl, W., P. Bratusch-Marrain, S. Gasic, A. Korn, and P. Nowotny. 1979. Insulin production rate following glucose ingestion estimated by splanchnic C-peptide output in normal man. Diabetologia. 17:221-227.

2. Eaton, R. P., R. C. Allen, D. S. Schade, K. M. Erickson, and J. Standefer. 1980. Prehepatic insulin production in man: kinetic analysis using peripheral connecting peptide behaviour. J. Clin. Endocrinol. Metab. 51:520-528.

3. Eaton, R. P., R. C. Allen, and D. S. Schade. 1983. Hepatic removal of insulin in normal man: dose response to endogenous insulin secretion. J. Clin. Endocrinol. Metab. 56:1194-1300.

4. Meistas, M. T., Z. Zadik, S. Margolis, and A. A. Kowarski. 1981. Correlation of urinary excretion of C-peptide with the integrated concentration and secretion rate of insulin. Diabetes. 30:639-643.

5. Meistas, M. T., M. Rendell, S. Margolis, and A. A. Kowarski. 1982. Estimation of the secretion rate of insulin from the urinary excretion rate of C-peptide: study in obese and diabetic subjects. Diabetes. 31:449-453.

6. Madison, L. L. 1969. Role of insulin in the hepatic handling of glucose. Arch. Intern. Med. 123:284-292.

7. Rubenstein, A. H., L. A. Pottenger, M. E. Mako, G. S. Getz, and D. F. Steiner. 1972. The metabolism of proinsulin and insulin by the liver. J. Clin. Invest. 51:912-921.

8. Kaden, M., P. Harding, and J. B. Field. 1973. Effect of intraduodenal glucose administration on hepatic extraction of insulin in the anesthetized dog. J. Clin. Invest. 52:2016-2028.

9. Harding, P. E., G. Bloom, and J. B. Field. 1975. Effect of infusion of insulin into portal vein on hepatic extraction of insulin in anesthetized dogs. Am. J. Physiol. 228:2580-2588.

10. Jaspan, J., and K. Polonsky. 1982. Glucose ingestion in dogs alters the hepatic extraction of insulin: in vivo evidence for a relationship between biologic action and extraction of insulin. J. Clin. Invest. 69: 516-525.

11. Polonsky, K., J. Jaspan, D. Emmanouel, K. Holmes, and A. R. Moossa. 1983. Differences in the hepatic and renal extraction of insulin and glucagon in the dog: evidence for saturability of insulin metabolism. Acta Endocrinol. 102:420-427.

12. Rubenstein, A. H., J. L. Clark, F. Melani, and D. F. Steiner. 1969. Secretion of proinsulin C-peptide by pancreatic beta cells and its circulation in blood. Nature (Lond.). 224:697-699.

13. Polonsky, K., J. B. Jaspan, W. Pugh, D. Cohen, M. Schneider, T. Schwartz, A. R. Moossa, H. Tager, and A. H. Rubenstein. 1983. Metabolism of C-peptide in the dog. In vivo demonstration of the absence of hepatic extraction. J. Clin. Invest. 72:1114-1123.

14. Polonsky, K. S., W. Pugh, J. B. Jaspan, D. M. Cohen, T. Karrison, H. S. Tager, and A. H. Rubenstein. 1984. C-peptide and insulin secretion. Relationship between peripheral concentrations of C-peptide and insulin and their secretion rates in the dog. J. Clin. Invest. 74:1821-1829.

15. Bratusch-Marrain, P. R., W. K. Waldhausl, S. Gasic, and A. Hofer. 1984. Hepatic disposal of biosynthetic human insulin and porcine C-peptide in humans. Metabolism. 33:151-157.

16. Faber, O. K., C. Hagen, C. Binder, J. Markussen, V. K. Naithani, P. M. Blix, H. Kuzuya, D. L. Horwitz, A. H. Rubenstein, and N. Rossing. 1978. Kinetics of human connecting peptide in normal and diabetic subjects. J. Clin. Invest. 62:197-203.

17. Frank, B. H., J. M. Pettee, R. E. Zimmerman, and P. J. Burek. 1981. The production of human proinsulin and its transformation into human insulin and C-peptide. In Peptides, Structure, and Biological Function. N. A. Rich and E. Gross, editors. Pierce Chemical Co., Rockford, IL. P729-738.
18. Metzler, C. M. 1971. Usefulness of the two-compartment open model in pharmacokinetics. J. Am. Statistical Association. 66:49-53.

19. Morgan, C. R., and A. Lazarow. 1963. Immunoassay of insulin: two antibody systems. Plasma insulin levels of normal subdiabetic and diabetic rats. Diabetes. 12:115-126.

20. Faber, O. K., C. Binder, J. Markussen, L. G. Heding, V. K. Naithani, H. Kuzuya, P. M. Blix, D. L. Horwitz, and A. H. Rubenstein. 1978. Characterization of seven C-peptide antisera. Diabetes. 27(Suppl): 170-177.

21. Blix, P. M., W. C. Boddie, R. L. Landau, H. Rochman, and A. H. Rubenstein. 1982. Urinary C-peptide: an indicator of beta cell secretion under different metabolic conditions. J. Clin. Endocrinol. Metab. 54:574-580.

22. Hendriksen, C., O. K. Faber, J. Drejer, and C. Binder. 1977. Prevalence of residual $\beta$-cell function in insulin treated diabetics evaluated by the plasma C-peptide response to intravenous glucagon. Diabetologia. 13:615-619.

23. Hoekstra, J. B. L., H. J. M. Van Rijn, D. W. Erkelens, and J. H. H. Thijssen. 1982. C-peptide. Diabetes Care. 5:438-446.

24. Scarlett, J. A., M. E. Mako, A. H. Rubenstein, P. M. Blix, J. Goldman, D. L. Horwitz, H. Tager, J. B. Jaspan, M. R. Stjernholm, and J. M. Olefsky. 1977. Factitious hypoglycemia: diagnosis by measurement of serum C-peptide immunoreactivity and insulin binding antibodies. N. Engl. J. Med. 297:1029-1032.

25. Rossell, R., R. Yomis, R. Casamitjana, R. Segura, E. Vilardell, and F. Rivera. 1983. Reduced hepatic insulin extraction in obesity: relationship with plasma insulin levels. J. Clin. Endocrinol. Metab. 56: 608-611.

26. Meistas, M. T., S. Margolis, and A. A. Kowarski. 1983. Hyperinsulinemia of obesity is due to decreased clearance of insulin. Am. J. Physiol. 245:E155-E159.

27. Bonora, E., I. Zavaroni, C. Coscelli, and N. Butturini. 1983. Decreased hepatic insulin extraction in subjects with mild glucose intolerance. Metabolism. 32:438-446.

28. Savage, P. J., E. V. Flock, M. E. Mako, P. M. Blix, A. H. Rubenstein, and P. H. Bennett. 1979. C-peptide and insulin secretion in Pima Indians and Caucasians: constant fractional hepatic extraction over a wide range of insulin concentrations and in obesity. J. Clin. Endocrinol. Metab. 48:594-598.

29. Sando, H., S. V. Lee, T. Iwamoto, M. Ikeuch, and K. Kosaka. 1980. Isoproterenol stimulated C-peptide and insulin secretion in diabetic and non-obese normal subjects: decreased hepatic extraction of endogenous insulin in diabetes. J. Clin. Endocrinol. Metab. 51:1143-1149.

30. Faber, O. K., K. Christensen, H. Kehlet, S. Madsbad, and C. Binder. 1981. Decreased insulin removal contributes to hyperinsulinemia in obesity. J. Clin. Endocrinol. Metab. 53:618-621.

31. Madsbad, S., H. Kehlet, J. Hilsted, and B. Troner. 1983. Discrepancy between plasma C-peptide and insulin response to oral and intravenous glucose. Diabetes. 32:436-438.

32. Waldhäusl, W. K., S. Gasic, P. Bratusch-Marrain, A. Korn, and P. Nowotny. 1982. Feedback inhibition by biosynthetic human insulin of insulin release in healthy human subjects. Am. J. Physiol. 243:E476E482.

33. Waldhäusl, W. K., P. Bratusch-Marrain, S. Gasic, A. Korn, and P. Nowotny. 1982. Insulin production rate, hepatic insulin retention and splanchnic carbohydrate metabolism after oral glucose ingestion in hyperinsulinemic Type II (non-insulin dependent) diabetes mellitus. Diabetologia. 23:6-15.

34. Waldhäusl, W. K., S. Gasic, P. Bratusch-Marrain, and P. Nowotny. 1983. The $75 \mathrm{~g}$ oral glucose tolerance test: effect on splanchnic metabolism of substrates and pancreatic hormone release in healthy men. Diabetologia. 25:489-495.

35. Polonsky, K. S., and A. H. Rubenstein. 1984. C-peptide as a measure of the secretion and hepatic extraction of insulin. Diabetes. 33: 486-494.

36. Sherwin, R. S., K. J. Kramer, J. D. Tobin, P. A. Insel, J. E. Liljenquist, M. Berman, and R. Andres. 1974. A model of the kinetics of insulin in man. J. Clin. Invest. 53:1481-1492. 